JEA Vol.1 Issue 1 Januari-Juni 2016 |36

\title{
UPAYA MENGEMBANGKAN KEMAMPUAN BAHASA DALAM MENGULANG \\ KALIMAT SEDERHANA MELALUI MODEL TALKING STICK PADA ANAK \\ KELOMPOK A PAUD TERPADU DARUNNAJAH MARTAPURA KABUPATEN
}

BANJAR

\author{
Oleh: Gusti Wasilah \\ (Mahasiswa S1 PG PAUD Universitas lambung Mangkurat)
}

\begin{abstract}
Abstrak
Rendahnya kemampuan bahasa anak Kelompok A Paud Terpadu Darunnajah Martapura Kabupaten Banjar dalam mengulang kalimat sederhana disebabkan siswa sulit memahami materi serta kurangnya penggunaan alat peraga dan tanpa adanya pengalaman langsung pada saat proses pembelajaran yang hanya berpatokan pada buku paket atau penjelasan guru saja. Hal ini terbukti Hal ini terbukti dari 15 orang anak, hanya 4 anak atau $27 \%$ yang berkembang sesuai harapan, sedangkan 11 anak atau $73 \%$ masih dikatagorikan belum berkembang. Untuk memperbaiki pengembangan bahasa anak maka digunakan model pembelajaran Talking Stick. Tujuan pelaksanaan penelitian adalah untuk mengetahui aktivitas guru saat melaksanakan pembelajaran, aktivitas anak saat mengikuti pembelajaran, dan hasil pengembangan kemampuan bahasa dalam mengulang kalimat sederhana pada anak Kelompok A Paud Terpadu Darunnajah Martapura Kabupaten Banjar.

Metode penelitian ini menggunakan Penelitian Tindakan Kelas (PTK) yang dilaksanakan sebanyak 2 siklus, siklus I dan siklus II terdiri dari masing-masing 2 pertemuan. Penelitian ini mengambil setting di Paud Terpadu Darunnajah Martapura Kabupaten Banjar pada semester I tahun pelajaran 2014/2015. Subjek penelitian ini adalah seluruh anak di kelompok A yang berjumlah 15 orang. Data diolah dengan interpretasi, distribusi frekuensi, dan persentase. Instrumen pengumpulan data melalui observasi guru, observasi anak dan hasil pengembangan kemampuan bahasa anak selama proses pembelajaran.

Hasil penelitian menunjukkan aktivitas guru dalam pelaksanaan pengembangan kemampuan bahasa anak dengan model Talking Stick dalam mengulang kalimat sederhana aktivitas guru terlaksana dengan katagori sangat baik. Aktivitas siswa pada siklus I dengan persentase $62 \%$ katagori aktif mengalami peningkatan menjadi $87 \%$ katagori sangat aktif. Hasil pengembangan kemampuan bahasa berkembang sesuai harapan dari siklus I $33 \%$ menjadi $100 \%$ pada siklus II.

Berdasarkan hasil penelitian dapat disimpulkan bahwa hasil pengembangan kemampuan bahasa pada materi mengulang kalimat sederhana melalui model Talking Stick pada anak Kelompok A Terpadu Darunnajah Martapura Kabupaten Banjar berkembang dengan signifikan dan hipotesa diterima.
\end{abstract}

Kata kunci: Kemampuan Bahasa, Talking Stick, Mengulang Kalimat Sederhana 


\section{Pendahuluan}

Pendidikan Anak Usia Dini (early child educational PAUD) sangat penting dilaksanakan sebagai dasar bagi pembentukan kepribadian manusia secara utuh, yaitu untuk pembentukan karakter, budi pekerti luhur, cerdas, ceria, terampil, dan bertaqwa kepada Tuhan Yang Maha Esa. Pendidikan Anak Usia Dini (PAUD) adalah suatu upaya pembinaan yang ditujukan kepada anak sejak lahir sampai dengan usia enam tahun yang dilakukan melalui pemberian rangsangan pendidikan untuk membantu pertumbuhan dan perkembangan jasmani dan rohani agar anak memiliki kesiapan dalam memasuki pendidikan lebih lanjut sedangkan taman kanak-kanak (TK) adalah salah satu bentuk pendidikan usia dini pada jalur pendidikan formal yang menyelenggarakan program pendidikan bagi anak usia dini empat sampai enam tahun (Depdikbud, 2011: 1).

Pada usia ini anak-anak berada pada masa yang peka untuk menerima rangsangan dari luar. Ia memiliki dunia dan karakteristik sendiri yang jauh berbeda dari orang dewasa. Pada tahap usia inilah seorang pendidik atau guru harus mengembangkan aspek-aspek perkembangan yang ada pada dirinya, masa ini sering disebut masa "golden age" dimana anak sangat peka mendapatkan rangsanganrangsangan baik yang berkaitan dengan aspek fisik motorik, intelektual, social, emosional maupun bahasa. Pendidikan anak usia dini diarahkan untuk memfasilitasi pertumbuhan dan perkembangan jasmani dan rohani anak agar dapat tumbuh secara sehat dan optimal sesuai dengan nilai, norma dan harapan masyarakat. Pendidikan ini dilakukan melalui pemberian pengalaman dan rangsangan yang kaya dan maksimal sehingga tercipta suatu lingkungan belajar dan perkembangan kondusif bagi pertumbuhan dan perkembangan anak (Syamsudin 2011: 1).

Pada saat lahir bayi dapat mendengarkan bunyi dari segala bahasa dan tidak terpaku pada satu pola bahasa saja. Kondisi ini memberikan kesempatan belajar bahasa sangat lentur. Pada usia lima atau enam tahun kemampuan untuk memahami bahasa sudah harus terbentuk, sedangkan kemampuan untuk menambah kosa kata tidak pernah berhenti. Artinya pembentukan dan penambahan kosa kata harus dilakukan melalui latihan berbicara dan anak diajak berkomunikasi secara terus menerus dengan kosa kata yang baru. Hal ini berarti komunikasi orang tua/orang dewasa dengan anak harus berjalan dengan lancar (Suriansyah, 2011 :28).

Anak usia 4-5 tahun rata-rata dapat mengungkapkan 900-1000 kosa kata yang berbeda. Mereka menggunakan 4-5 kata dalam suatu kalimat yang dapat berbentuk kalimat pernyataan, negative, Tanya dan perintah. Owens mengemukakan bahwa anak usia dini tersebut memperkaya kosa katanya 
melalui pengulangan. Mereka sering mengulangi kosa kata yang baru dan urut sekalipun mungkin belum memahami artinya. Dalam mengembangkan kosa kata tersebut, anak menggunakan fast mapping yaitu suatu proses dimana anak menyerap arti kata baru setelah mendengarkan sekali atau dua kali dalam percakapan. Pada masa kanak-kanak inilah anak mulai mengkombinasikan suku kata menjadi kata,dan kata menjadi kalimat. (Dhieni,2011: 3.1).

Salah satu aspek yang penting yang perlu di kembangkan di Taman Kanak-Kanak adalah pengembangan bahasa diharapkan dapat meningkatkan kemampuan dan kreativitas anak sesuia dengan tahap perkembangannya. Bahasa merupakan bagian dari kemampuan anak dalam membaca dan menulis. Lingkup perkembangan bahasa dengan tingkat pencapaian perkembangan mengerti beberapa perintah secara bersamaan adalah materi pelajaran bahasa yang perlu dicapai anak Taman Kanak-Kanak (TK) dalam kelompok umur 4-6 tahun sebagai acuan pada jenjang SD. Adapun tujuan dari penyelenggaraan pendidikan di Taman Kanak-Kanak adalah membantu anak didik mengembangkan berbagai potensi baik psikis dan fisik yang meliputi moral dan nilai-nilai agama,sosial, emosional, bahasa, kognitif fisik motorik, kemandirian dan seni untuk mempersiapkan memasuki pendidikan dasar (Sudrajat,2008: online).
Pengembangan bahasa pada anak usia TK perlu mendapat perhatian penting, mengingat bahwa bahasa merupakan pusat dari pengembangan aspek-aspek yang lain. Menjadi kewajiban orang tua dan guru untuk melakukan berbagai usaha dalam pengembangan keterampilan berbahasa anak melalui berbagai kegiatan didalam atau di luar kelas, dan kegiatan permainan bahasa yang menyenangkan anak (Dhieni, 2011: 9.1).

Pada kenyataannya, berkaitan dengan permasalahan yang terjadi pada bidang pengembangan kemampuan berbahasa, peneliti menemukan bahwa anak mengalami kesulitan untuk mengulang kalimat sederhana di kelompok PAUD Terpadu Darunnajah Martapura Kabupaten Banjar. Dari hasil observasi 15 orang anak dalam satu kelas hanya 4 anak atau sekitar $27 \%$ dari jumlah keseluruhan anak dalam satu kelas yang yang paham atau berkembang sesuai harapan, sedangkan yang 11 orang anak atau $73 \%$ masih dikategorikan mulai berkembang. Hal ini disebabkan oleh beberapa faktor permasalahan baik dari guru, anak maupun sumber belajar sebagai pendukungnya, karena masih kurangnya kemampuan dan peran dari orang tua serta guru dalam mengembangkan bahasa dalam mengulang kalimat sederhana, model pembelajaran yang kurang menarik minat, metode yang digunakan adalah metode ceramah kegiatan pembelajaran berpusat pada guru, media yang 
digunakan kurang menarik dan anak pasif mendengarkan penjelasan guru sehingga seharusnya menyenangkan menjadi kurang menarik minat anak dan anak asyik dengan kegiatannya sendiri.

Rendahnya tingkat kemampuan anak dalam berbicara apabila dibiarkan akan membawa dampak tidak optimalnya perkembangan bahasa anak yang berhubungan dengan kesulitan dalam berkomunikasi, mengungkapkan pikiran dan perasaannya melalui bahasa lisan, dan berinteraksi dengan lingkungan. Untuk mengatasi masalah tersebut maka perlu bagi seorang pendidik dalam menyiapkan model pembelajaran yang menyenangkan bagi anak, yaitu melalui model pembelajaran Talking Stick.

Talking stick atau tongkat berjalan termasuk salah satu model pembelajaran kooperatif. Model pembelajaran ini dilakukan dengan bantuan tongkat, siapa yang memegang tongkat wajib menjawab pertanyaan dari guru, setelah anak diajarkan materi pokoknya. Model Talking Stick menjadi salah satu tipe dalam model pembelajaran yang dapat mengembangkan kemampuan siswa mengembangkan bahasanya. Kelebihan model Talking Stick adalah menguji kesiapan siswa, mendorong anak untuk mengungkapkan pendapatnya masingmasing, melatih keterampilan berbicara anak, melatih membaca dan memahami lebih cepat, menciptakan suasana menyenangkan sehingga membuat anak lebih giat dan menyenangi pembelajaran (Jamaludin, 2011: Online).

\section{Kajian Teori}

\section{Karakteristik Perkembangan Anak Usia Dini}

Anak usia dini memiliki karakteristik yang khas. Menurut Hartati (Aisyah, 2007: 1-

4) beberapa karakteristik anak usia dini tersebut adalah sebagai berikut.

a. Memiliki rasa ingin tahu yang besar Anak usia dini sangat tertarik dengan dunia sekitarnya. Dia ingin mengetahui segala sesuatu yang terjadi di sekelilingnya.

b. Merupakan pribadi yang unik Meskipun banyak terdapat kesamaan dalam pola umum perkembangan, setiap anak meskipun kembar memiliki keunikan masing-masing, misalnya dalam hal gaya belajar, minat, dan latar belakang keluarga.

c. Suka berfantasi dan berintegrasi Anak usia dini sangat suka membayangkan dan mengembangkan berbagai hal jauh melampaui kondisi nyata.

d. Masa paling potensial untuk belajar Anak usia dini sering juga disebut dengan istilah golden age atau usia emas, karena pada rentang usia ini anak mengalami pertumbuhan dan perkembangan yang sangat pesat pada berbagai aspek. 
e. Menunjukkan sikap egosentris

Egosentris artinya berpusat pada aku, maksudnya bahwa anak usia dini pada umumnya hanya memahami sesuatu dari sudut pandangnya sendiri, bukan sudut pandang orang lain.

f. Memiliki rentang daya konsentrasi yang pendek

Seringkali kita saksikan bahwa anak usia dini cepat sekali berpindah dari suatu kegiatan ke kegiatan yang lain. Anak usia dini memang mempunyai rentang perhatian yang sangat pendek sehingga perhatiannya mudah teralihkan pada kegiatan lain.

g. Sebagai bagian dari makhluk sosial Anak usia dini mulai suka bergaul dan bermain dengan teman sebayanya. Ia mulai belajar berbagi, mengalah, dan antri menunggu giliran saat bermain dengan teman-temannya.

\section{Perkembangan Bahasa Anak Usia Dini}

Bahasa adalah segala bentuk komunikasi di mana pikiran dan perasaan seseorang disimbolisasikan agar dapat menyampaikan arti kepada orang lain. Oleh karena tiu, perkembangan bahasa dimulai dari tangisan pertama sampai anak mampu bertutur kata. Perkembangan bahasa terbagi menjadi dua periode, yaitu, periode Prelinguistik dan periode Linguistik. Periode Linguistik inilah anak mulai mengucapkan kata-kata pertama.
Pada usia Taman Kanak-Kanak (4-6 tahun), perkembangan berbahasa anak ditandai oleh berbagai kemampuan sebagai berikut:

a. Mampu menggunakan kata ganti saya dalam berkomunikasi.

b. Memiliki berbagai perbendaharaan kata kerja, kata sifat, kata keadaan, kata tanya dan kata sambung.

c. Menunjukkan pengertian dan pemahaman tentang sesuatu.

d. Mampu menggungkapkan pikiran, perasaan, dan tindakan dengan menggunakan kalimat sederhana.

e. Mampu membaca dan mengungkapkan sesuatu melalui gambar

Perkembangan kemampuan tersebut muncul ditandai oleh berbagai gejala seperti senang bertanya dan memberikan informasi tentang berbagai hal, berbicara sendiri, dengan atau tanpa menggunakan alat seperti (boneka, mobil mainan, dan sebagainya). Mencoretcoret buku atau dinding dan menceritakan sesuatu yang fantastik. Gejala-gejala ini merupakan pertanda munculnya kepermukaan berbagai jenis potensi tersembunyi (hidden potency) menjadi potensi tampak (actual potency). Kondisi tersebut menunjukkan berfungsi dan berkembangnya sel-sel saraf pada otak. (Depdikbud, 2000: 6).

Perkembangan bahasa anak dapat dibagi ke dalam tiga aspek, yaitu: 
1) Kosakata. Seiring dengan perkembangan anak dan pengalamannya berinteraksi dengan lingkungannya, kosakata anak berkembang dengan pesat.

2) Sintaksis (tata bahasa). Walaupun anak belum mempelajari tata bahasa, akan tetapi melalui contoh-contoh berbahasa yang didengar dan dilihat anak di lingkungannya, anak telah dapat menggunakan bahasa lisan dengan susunan kalimat yang baik. Misalnya, "Rita memberi makan kucing" bukan "Kucing Rita makan memberi".

3) Semantik, maksudnya penggunaan kata sesuai dengan tujuannya. Anak di Taman Kanak-kanak sudah dapat mengekspresikan keinginan, penolakan, dan pendapatnya dengan menggunakan kata-kata dan kalimat yang tepat. Misalnya, "tidak mau" untuk menyatakan penolakan (Susanto Ahmad, $2011: 77$ )

Perkembangan bahasa anak tidak saja dipengaruhi oleh perkembangan neurologis tetapi juga oleh perkembangan biologisnya. Perkembangan bahasa seorang anak itu mengikuti dan sesuai dengan perkembangan biologisnya yang tidak dapat ditawar-tawar. Seorang anak tidak dapat dipaksa atau dipicu untuk sekuat apapun untuk dapat mengujarkan/mengucapkan sesuatu, bila saja kemampuan biologisnuya belum memungkinkan untuk mengujarkan suatu kata. Sebaliknya, bila anak secara biologis telah dapat mengucapkan/mengujarkan sesuatu, maka dia tidak akan dapat dicegah/ditahan untuk mengujarkan/mengucapkan (Martinis Yamin, 2010: 137).

Menurut Montolalu (2009: 9.30-9.31) tujuan perkembangan bahasa adalah sebagai berikut:

a. Berkomunikasi dengan orang lain.

b. Menambah kosakata

c. Membagi pengalaman dengan orang lain

d. Mulai berpartisipasi dalam perencanaan kelompok berdiskusi masalah-masalah bersama mengungkapkan perasaan dan pikiran. Menjadi lebih mahir dan ekspresif dalam bermain dramatisasi menjalin hubungan pertemanan.

Sedangkan menurut Dhinie (2009:1.17) bahasa memiliki karakteristik yang menjadikannya bentik khas komunikasi, yaitu sistematis, artinya bahasa merupakan suatu cara menghubungkan bunyi-bunyian maupun tulisan yang bersifat teratur standar khas. Arbitrari, yaitu bahwa bahasa terdiri dari hubungan-hubungan antara berbagai macam suara dan visual, objek, maupun gagasan. Fleksibel, artinya bahasa dapat berubah dengan perkembangan zaman. Beragam, artinya dalam hal pengucapan, bahasa memiliki berbagai variasi dialek atau cara. Kompleks, artinya bahwa kemampuan berpikir dan bernalar dipengaruhi oleh 
kemampuan menggunakan bahasa yang menjelaskan berbagai konsep, ide maupun hubungan-hubungan yang dapat dimanipulasikan saat berpikir dan bernalar.

\section{Berbicara}

Bicara menurut Kamus Bahasa Indonesia (2008:196) adalah pertimbangan pikiran, pendapat, akal budi, pikiran, berkata, beromong, bercakap, berbahasa, melahirkan pendapat (dengan perkata, tulisan dsb).

Keterampilan berbicara dapat ditunjukkan oleh anak dalam perilaku, mengembangkan keterampilan bertanya, menyiapkan kegiatan yang dapat dilakukan di dalam maupun di luar kelas, menciptakan suasana belajar yang menyenangkan dan menggunakan berbagai kegiatan yang bervariasi (Depdiknas, 2007:5).

Tujuan utama dari berbicara adalah untuk berkomunikasi, agar dapat menyampaikan pikiran secara efektif, alangkah baiknya pembicara memahami makna segala sesuatu yang ingin dikomunikasikan. Dia harus mampu mengevaluasi efek komunikasinya terhadap para pendengarnya dan harus mengetahui prinsip-prinsip yang mendasari segala situasi pembicaraan baik secara umum maupun perorangan (Tarigan, 2008:16).

Kegiatan pengembangan berbicara anak akan mempunyai manfaat dalam kegiatan berbahasa lisan anak. Secara umum tujuan pengembangan berbicara anak usia dini yaitu agar anak mampu mngungkapkan isi hatinya (pendapat, sikap) secara lisan dengan lafal yang tepat untuk kepentingan berkomunikasi. Bila dipelajari dari tujuan tersebut, ada tiga tujuan umum dalam pengembangan berbicara anak. 1) agar anak dapat melafalkan bunyi bahasa yang digunakan secara tepat; 2) agar anak mempunyai perbendaharaan kata yang memadai untuk keperluan berkomunikasi; 3) agar anak mampu menggunakan kalimat secara baik untuk berkomunikasi secara lisan (Suhartono, 2005:123).

\section{Model Pembelajaran Talking Stick}

Pembelajaran kooperatif merupakan suatu model pembelajaran dimana anak belajar dalam kelompok-kelompok kecil yang memiliki tingkat kemampuan yang berbeda. Dalam menyelesaikan tugas kelompok, setiap anggota saling bekerja sama dan membantu untuk memahami suatu bahan pembelajaran. Model pembelajaran kooperatif dapat member keuntungan baik bagi anak kelompok bawah maupun kelompok atas yang bekerja bersama dalam menyelesaikan tugas-tugas akademik (Rahmadiarti, 2003:21).

Ibrahim (2000:21) menyatakan bahwa "Pembelajaran kooperatif dicirikan oleh struktur tugas, tujuan dan pengalaman kooperatif". Anak yang bekerja dalam situasi pembelajaran kooperatif didorong atau dikehendaki untuk bekerja sama pada suatu tugas bersama, dan anak harus mengkoordinasikan usahanya untuk 
menyelesaikan tugasnya. Dalam penerapan model pembelajaran kooperatif, dua atau lebih individu saling tergantung satu sama lain untuk mencapai satu penghargaan bersama. Kelompok anak akan berbagi penghargaan seandainya berhasil dalam memecahkan masalah yang diajarkan kepada kelompok pembelajaran.

Salah satu metode yang efektif dari berbagai metode pembelajaran yaitu pembelajaran kooperatif tipe Talking Stick. Model pembelajaran tipe Talking Stick ini menggunakan sebuah tongkat sebagai alat penunjuk giliran. Siswa yang mendapat tongkat akan diberikan pertanyaan dan harus menjawabnya. Kemudian secara estafet tongkat tersebut berpindah ketangan siswa lainnya secara bergiliran. Demikian seterusnya sampai semua siswa mendapat tongkat dan pertanyaan.

"Model pembelajaran Talking Stick adalah suatu model pembelajaran dengan bantuan tongkat, anak yang memegang tongkat lebih dahulu wajib menjawab pertanyaan dari guru setelah siswanya mempelajari materi pokoknya, selanjutnya kegiatan itu diulang terus menerus sampai seluruh anak mendapat pertanyan dan mengungkapkan pendapatnya" (Jamaludin. 2011: Online).

Suprijono (2009:109) mengungkapkan bahwa "Model talking stick mendorong peserta didik untuk berani mengemukakan pendapat". Model talking stick ini sangat tepat digunakan dalam pengembangan proses pembelajaran partisipatif, aktif, inovatif, kreatif, efektif, dan menyenangkan.

Apabila kita lihat dari pendapat di atas mengenai model pembelajaran talking stikc yakni diharapkan setelah anak mengikuti proses pembelajaran dengan menggunakan model talking stikc ini dapat memperoleh banyak pengetahuan dan keterampilan. Anak menjadi termotivasi untuk belajar lebih giat, kegiatan belajar menjadi menyenangkan dan tidak membosankan.

Langkah-langkah pembelajaran menurut model Talking Stick adalah:

a. Guru menyiapkan sebuah tongkat

b. Guru menyampaikan materi pokok yang akan dipelajari

c. Guru memberikan kesempatan dan membimbing anak untuk mempelajari materi

d. Guru mengambil tongkat dan memberikan kepada anak, setelah itu guru memberikan pertanyaan dan anak menjawab pertanyaan dan anak yang memegang tongkat tersebut harus menjawabnya, demikian seterusnya sampai sebagian besar anak mendapat bagian untuk menjawab setiap pertanyaan guru.

e. Guru bersama anak menyimpulkan pelajaran (Tim Instruktur, 2010: 27).

Setiap pembeajaran pasti memiliki kelebihan dan kekurangan, untuk itu dengan adanya 
pembelajaran terpadu maka pengembangan model yang bervariasi dapat membantu pencapaian tujuan tiap materi pembelajaran. Demikian pula dengan model Talking Stick memiliki kelebihan dan kekurangan. Adapun kelebihan dan kekurangan dari model talking stikc menurut Suprijono (2010:110) sebagai berikut :

Kelebihan model Talking Stick adalah:

a. Menguji kesiapan anak

b. Melatih anak membaca dan memahami materi dengan cepat

c. Memacu anak agar lebih giat belajar

d. Anak berani mengemukakan pendapat.

Kekurangan model Talking Stick yaitu membuat anak senam jantung. Apabila kita lihat dari pernyataan terdapat berbagai kelebihan dna kekurangan model Talking Stick mungkin hal ini lumrah terjadi bahwa setiap model pembelajaran pun mempunyai beberapa keunggulan dan kelemahan tergantung bagaimana proses pembelajaran itu sendiri dan seorang guru sebagai pembimbing agar model Talking Stick berhasil diterapkan pada anak sesuai dengan harapan dalam tujuan pembelajaran Talking Stick itu sendiri.

\section{Metode Penelitian}

\section{Pendekatan Penelitian}

Pendekatan yang digunakan dalam penelitian ini adalah pendekatan kualitatif yaitu pendekatan yang berpedoman pada aktivitas siswa dalam upaya mengembangkan bahasa pada materi menjawab pertanyaan sederhana, sedangkan penelitian ini tergolong penelitian tindakan kelas (classroom action research) yang terdiri atas tahapan-tahapan perencanaan, pelaksanaan tindakan, observasi dan evaluasi, analisi dan refleksi.

\section{Setting Penelitian}

Penelitian dilaksanakan di Paud Terpadu Darunnajah Martapura Kabupaten banjar yang beralamat di Jl. Veteran Kelurahan Sungai Sipai Martapura Kota Kabupaten Banjar. Jumlah anak kelompok A sebanyak 15 orang terdiri dari 10 orang laki-laki, dan 5 orang anak perempuan.

\section{Skenario Tindakan}

Penelitian tindakan kelas ini direncanakan terdiri dari dua siklus. Tiap siklus dilaksanakan dalam dua pertemuan. Tiaptiap siklus direncanakan berkesinambungan, artinya proses dan hasil siklus 1 akan ditindak lanjuti dalam siklus 2. Prosedur penelitian tindakan kelas ini setiap siklus meliputi: (1) perencanaan (planing); (2) tindakan (acting); (3) observasi (observing); (4) evaluasi (evaluating); (5) refleksi (reflekting).

\section{Data dan Cara Pengumpulan Data}

Untuk memperoleh informasi yang valid dan realibel dari pelaksanaan penelitian tindakan 
ini, maka perlu kelengkapan data, kualitas alat pengumpul data dan ketepatan alat analisanya.

\section{a. Sumber Data}

Data yang diperoleh adalah data tentang aktivitas guru dalam melaksanakan kegiatan pembelajaran melalui model Talking Stick dengan menggunakan lembar observasi dan data tentang kegiatan anak dalam mengulang kalimat sederhana melalui model Talking Stick dengan mengunakan lembar observasi.

\section{b. Cara Pengambilan Data}

1. Data aktifitas anak diambil melalui observasi pada proses kegiatan pembelajaran mengulang kalimat sederhana melalui model Talking Stick.

2. Data hasil pengembangan bahasa anak melalui model Examples Talking Stick. dapat dilakukan dengan menggunakan lembar kerja siswa (LKS) dan LKK.

\section{Hasil Penelitian}

Pelaksanaan Tindakan Kelas Siklus I

\section{Pertemuan I}

\section{Hasil Observasi}

\section{Aktivitas guru}

Dari hasil observasi terhadap aktivitas guru selama pembelajaran diatas menunjukkan bahwa semua aspek aktivitas guru yang telah direncanakan oleh peneliti dapat terlaksana sepenuhnya, namun belum optimal, sehingga perlu adanya perbaikan aktivitas guru dalam proses melalui model Talking Stick pembelajaran agar hasil belajar siswa meningkat pada pertemuan berikutnya.

2. Aktivitas anak

Anak belum terbiasa dengan model pembelajaran yang digunakan, sehingga mereka kurang tanggap terhadap aturan yang ada. Beberapa anak sudah berani maju kedepan tetapi dengan bujukan dan rayuan guru, anak sudah mau bekerjsama dalam kelompok namun hanya sebagian kecil anak saja, dan anak sudah dapat mengulang kembali kalimat yang telah diperdengarkan tetapi hanya sebagian kecil anak saja.

Data hasil aktivitas anak pada siklus I pertemuan 1 ini dapat dilihat pada grafik di bawah ini:

Berikut adalah grafik aktivitas anak pertemuan 1 siklus I :

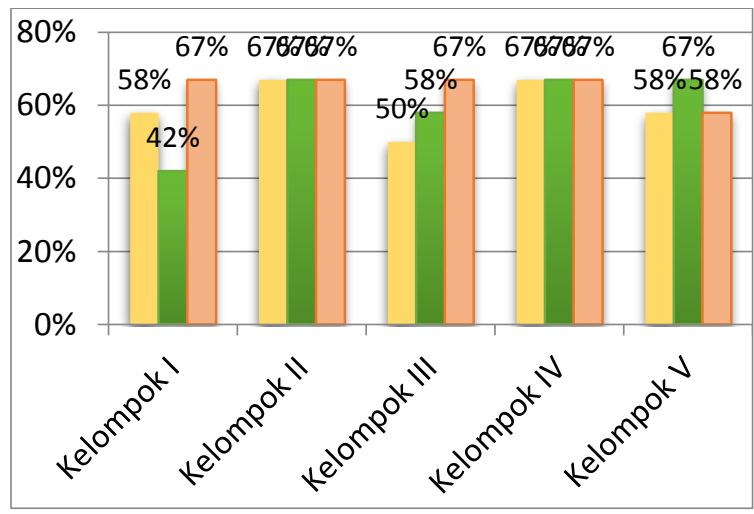

Grafik Aktivitas Anak Siklus I Pertemuan 1 
Keterangan:

Keberanian

Kerjasama

Ketepatan

3. Hasil pengembangan

Hasil pengembangan bahasa dalam mengulang kalimat sederhana yaitu ada anak yang mendapat $*$ dengan persentase $13 \%$, anak yang mendapat $* *$ dengan persentase 54 $\%$, anak yang mendapat $* * * 33 \%$ dan tidak ada anak yang mendapat $* * * *$. Hasil belajar anak pada pertemuan 1 siklus I sebesar $33 \%$, hal ini berarti ketuntasan klasikal belum tercapai karena nilai ketuntasan kurang dari indikator keberhasilan yang ditetapkan yaitu $80 \%$.

\section{Pelaksanaan Tindakan Kelas Siklus I Pertemuan II}

\section{Hasil Observasi}

1. Aktivitas guru

Guru mengalami perbaikan dari pertemuan sebelumnya, tetapi masih belum optimal yaitu ada indikator/aspek yang belum terlaksana dengan baik yaitu pada aspek guru memberi kesempatan kepada anak untuk mempelajari materi, tetapi guru belum membimbing anak. Sehingga perlunya perbaikan paa pertemuan berikutnya.

2. Aktivitas anak
Perkembangan aktivitas anak pada aspek keberanian, kerjasama, ketepatan melalui model pembelajaran Talking Stick mengalami peningkatan, rata-rata kelompok memperoleh persentase $68 \%$ dengan katagori aktif, tetapi belum mencapai indikator yang ditetapkan yaitu $80 \%$. Hal ini menunjukkan bahwa aktivitas siswa dalam kegiatan pembelajaran masih perlu ditingkatkan lagi pada pertemuan berikutnya agar keaktifan siswa meningkat.

Data hasil aktivitas anak pada siklus I pertemuan 2 ini dapat dilihat pada grafik di bawah ini:

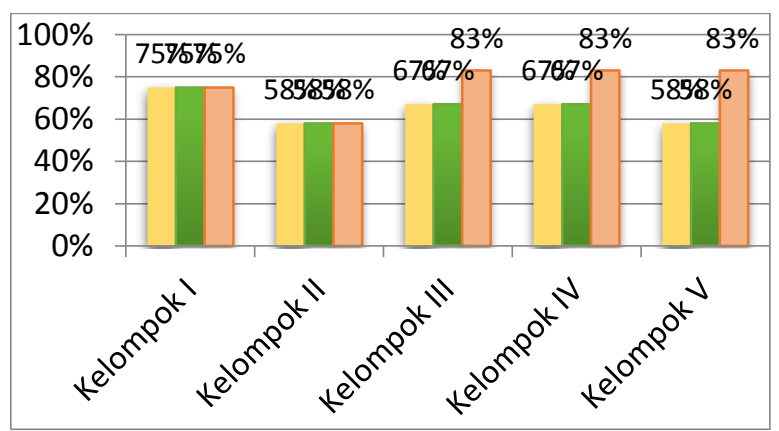

Grafik Aktivitas Anak Siklus I

Pertemuan 2

Keterangan :

Keberanian

Kerjasama

Ketepatan

3. Hasil pengembangan 
Hasil pengembangan bahasa pada pertemuan 2 siklus I Penelitian Tindakan Kelas ini dapat digambarkan pada grafik berikut:

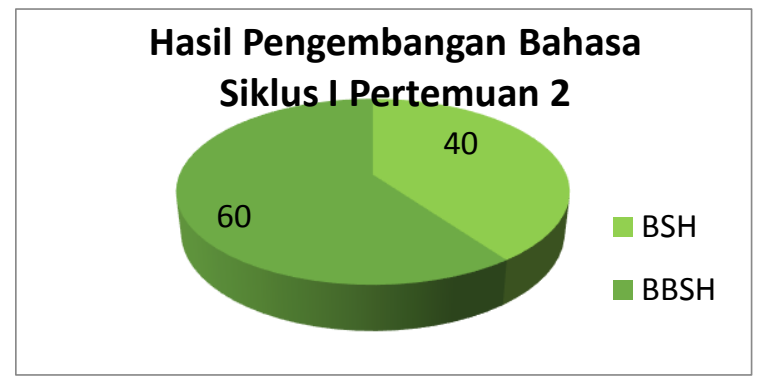

Diagram Lingkaran Hasil Pengembangan Klasikal Siklus I Pertemuan 2

Berdasarkan indikator keberhasilan penelitian tindakan kelas ini yakni pencapaian perkembangan aspek bahasa dalam mengulang kalimat sederhana dikatakan berhasil apabila individu mencapai minimal BSH serta klasikal $80 \%$ siswa mendapat nilai berkembang sesuai harapan $(\mathrm{BSH}=$ bintang $* * *)$.

Hasil pengembangan bahasa dalam mengulang kalimat sederhana yaitu tidak ada anak yang mendapat *, anak yang mendapat ** ada 9 orang anak persentase $60 \%$, anak yang mendapat $* * *$ ada 6 orang anak persentase $40 \%$. Hasil pengembangan bahasa pada pertemuan 2 siklus I sebesar $60 \%$, hal ini berarti ketuntasan klasikal mengalami peningkatan, tetapi belum mencapai indikator keberhasilan yaitu $80 \%$.

\section{Refleksi Siklus I}

a. Aktivitas Guru
Berdasarkan hasil pengamatan melalui format observasi guru hasil penelitian menunjukan aktivitas guru siklus I pada pertemuan pertama sesuai langkah-langkah memperoleh skor 11 dengan kriteria baik berarti belum mencapai ketuntasan yang sudah ditetapkan yaitu jika memperoleh skor 16-20 dengan kriteria sangat baik. Pada pertemuan kedua mengalami perbaikan yaitu memperoleh skor 15 dengan kriteria baik, tetapi belum mencapai ketuntasan yang diharapkan yaitu jika memperoleh skor 16-20 dengan kriteria sangat baik.

Aktivitas guru dikatakan belum optimal yaitu ada beberapa indikator/aspek yang belum terlaksana dengan baik yaitu pada aspek guru menyampaikan materi pokok yang akan dipelajari tetapi penyampaian materi belum jelas, sehingga pada pertemuan berikutnya guru harus melakukan perbaikan-perbaikan yaitu guru memberi kesempatan dan bimbingan kepada anak seluruh anak untuk mempelajari materi, guru mengambil tongkat dan memberikan kepada anak, setelah itu guru memberikan pertanyaan, dan memberikan pertanyaan kepada seluruh anak, guru melibatkan seluruh anak dalam menyimpulkan pelajaran, serta pentingnya pengelolaan waktu dan pembimbingan anak untuk kelancaran model Talking Stick.

b. Aktivitas Anak

Temuan pada hasil observasi anak pada siklus I pertemuan 1 memperoleh nilai dengan rata- 
rata $62 \%$ dengan katagori aktif pada aspek keberanian, kerjasama, ketepatan, belum mencapai ketuntasan yang diharapkan yaitu $80 \%$. Hal ini disebabkan karena anak belum terbiasa dengan model pembelajaran tipe Talking Stick. Anak masih kesulitan dalam mengulang kalimat sederhana. Pada pertemuan kedua terjadi peningkatan dengan persentase rata-rata $68 \%$ kategori aktif. Anak sudah mulai terbiasa dengan model pembelajaran yang digunakan, tetapi beberapa anak sudah berani maju kedepan tetapi dengan bujukan dan rayuan guru, anak sudah mau bekerjsama dalam kelompok namun hanya sebagian kecil anak saja, dan anak sudah dapat mengulang kembali kalimat yang telah diperdengarkan tetapi hanya sebagian kecil anak saja. Penelitian ini akan dilanjutkan pada siklus II untuk lebih meningkatkan aktivitas anak, guru juga akan menjadi berusaha menjadi fasilitator yang baik untuk memotivasi siswa supaya aspek keberanian, kerjasama, ketepatan, dalam bermain Taling Stick dapat tercapai dengan lebih baik lagi. Perbaikan-perbaikan yang akan dilakukan berlaku untuk semua kelompok dan semua aspek. Guru harus lebih memotivasi anak untuk meningkatkan antusias dan keberanian anak. Guru harus lebih menanamkan kepada anak pentingnya saling bekerjasama dan saling membantu dengan teman kelompok.

c. Hasil Pengembangan
Hasil pengembangan bahasa pada siklus I pertemuan 1 ketuntasan klasikal $33 \%$ belum memenuhi kriteria yang telah ditentukan. Hal ini dikarenakan masih ada anak yang belum tepat dalam mengulang kalimat sederhana. Pada pertemuan 2 mengalami peningkatan 60 $\%$, hasil yang diperoleh belum mencapai hasil yang diharapkan. Penelitian ini akan dilanjutkan lagi pada siklus II. Untuk menjadikan hasil pengembangan yang lebih optimal lagi, peneliti melaksanakan dan mempelajari model pembelajaran dengan tipe Talking Stick dengan lebih baik lagi dengan berusaha sebaik mungkin membimbing dan mengarahkan, guru dalam penyampaian materi akan berperan sebagai teman anak sehingga anak terdorong untuk memperhatikannya, menjadi fasilitator anak untuk mengembangkan aspek-aspek perkembangannya, guru harus menyampaikan materi yang lebih jelas kepada anak pada pertemuan berikutnya yang akan dijadikan sebagai soal evaluasi sehingga ketuntasan individual dan klasikal dapat tercapai.

Pelaksanaan Tindakan Kelas Siklus II Pertemuan I

\section{Hasil Observasi}

\section{a. Aktivitas Guru}

Dari hasil observasi terhadap aktivitas guru selama pembelajaran diatas menunjukkan bahwa semua aspek aktivitas guru yang telah direncanakan oleh peneliti dapat terlaksana 
sepenuhnya, guru melakukan perbaikanperbaikan. Penelitian akan dilanjutkan pada pertemuan berikutnya, agar pelaksanaan pembelajaran melalui model Talking Stick lebih baik lagi.

\section{b. Aktivitas Anak}

Perkembangan aktivitas anak pada aspek keberanian, kerjasama, ketepatan melalui model pembelajaran Talking Stick mengalami peningkatan, rata-rata kelompok memperoleh persentase $81 \%$ dengan katagori sangat aktif. Hal ini menunjukkan bahwa aktivitas anak mencapai indikator yang ditetapkan yaitu 76$100 \%$. Penelitian akan dilanjutkan pada pertemuan berikutnya agar aktivitas anak lebih aktif lagi.

Data hasil aktivitas anak pada siklus II pertemuan 1 ini dapat dilihat pada grafik di bawah ini:

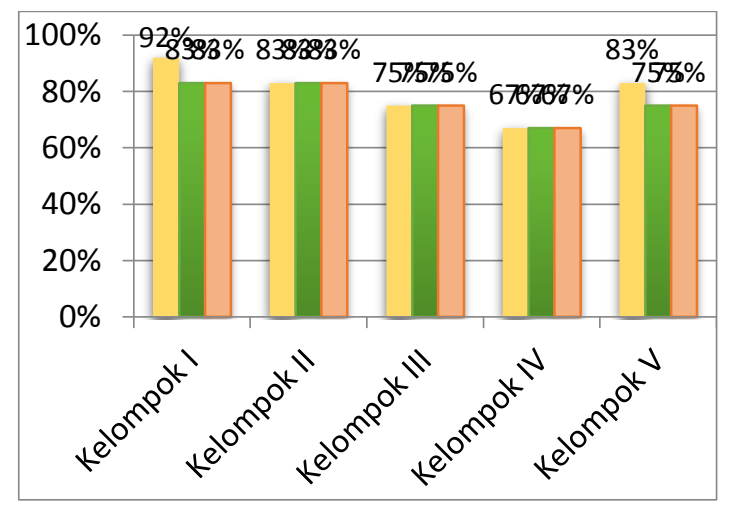

Grafik Aktifitas Anak Siklus II

Pertemuan 1

Keterangan :
Keberanian

Kerjasama

Ketepatan

\section{c. Hasil Pengembangan}

Hasil pengembangan klasikal pengembangan bicara untuk siklus II Penelitian Tindakan Kelas ini dapat digambarkan pada grafik berikut:

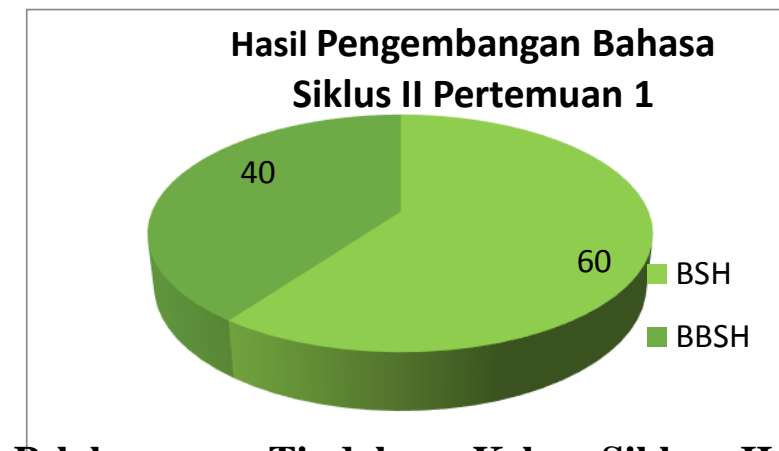

Pelaksanaan Tindakan Kelas Siklus II

\section{Pertemuan II}

\section{Hasil Observasi}

\section{a. Aktivitas Guru}

Dari hasil observasi terhadap aktivitas guru selama pembelajaran diatas menunjukkan bahwa semua aspek aktivitas guru yang telah direncanakan oleh peneliti dapat terlaksana sepenuhnya, guru telah melakukan perbaikanperbaikan.

\section{b. Aktivitas Anak}

Perkembangan aktivitas anak pada aspek keberanian, kerjasama, ketepatan melalui model pembelajaran Talking Stick mengalami peningkatan, rata-rata kelompok memperoleh persentase $87 \%$ dengan katagori sangat aktif. 
Hal ini menunjukkan bahwa aktivitas anak mencapai indikator yang ditetapkan yaitu 80 $\%$. Aktivitas anak secara berkelompok mengalami peningkatan

\section{c. Hasil Pengembangan}

Hasil pengembangan klasikal pengembangan bahasa untuk siklus II Penelitian Tindakan Kelas ini dapat digambarkan pada grafik berikut:

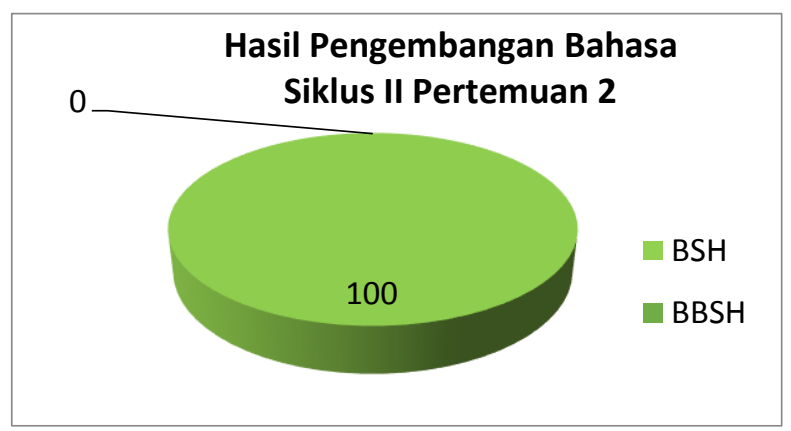

\section{Refleksi Siklus II}

a. Aktivitas Guru

Kegiatan pembelajaran yang dilakukan guru sudah berjalan efektif, dengan dilaksanakannya perbaikan-perbaikan yang telah direncanakan pada refleksi siklus I, hal ini terlihat dari aspek yang diobservasi sudah sepenuhnya dilaksanakan guru dengan sangat baik dan optimal. Pada siklus II pertemuan 1 aktivitas guru telah terlaksana memperoleh skor 18 dengan kriteria sangat baik. Pada siklus II pertemuan 2 aktivitas guru telah terlaksana memperoleh skor 20 dengan kriteria sangat baik. Hal ini menunjukkan keberhasilan aktivitas yang dilaksanakan guru yang sesuai indikator jika mencapai skor 1620 dengan katagori sangat baik.

b. Aktivitas Anak

Pada siklus II pertemuan 1 aktivitas anakanak nilai rata-rata yang diperoleh adalah 81 $\%$ dengan kategori sangat aktif. Pada pertemuan 2 aktivitas anak memperoleh persentase $87 \%$ dengan katagori sangat aktif. Hal ini berarti aktivitas anak telah mencapai indikator keberhasilan $80 \%$. Berdasarkan data hasil pengamatan observer, aktivitas anak juga menunjukkan adanya perkembangan terhadap pembelajaran yang disampaikan sebab dari beberapa aspek telah menunjukkan adanya perbaikan yang diharapkan. dengan kategori sangat aktif dan sudah mencapai indikator keberhasilan yang diharapkan (memuaskan).

c. Hasil Pengembangan.

Hasil pengembangan yang diperoleh sudah mencapai indikator keberhasilan yang diharapkan yaitu $100 \%$ tuntas mendapatkan $\geq(* * *)$ artinya berkembang sesuai harapan, berdasarkan dari temuan data diatas dapat dinyatakan pembelajaran dengan menerapkan Model Talking Stick sudah mencapai target atau indikator-indikator yang telah ditetapkan sebelumnya.

\section{Pembahasan}

Berdasarkan hasil Penelitian Tindakan Kelas yang dilaksanakan pada siklus I dua kali pertemuan dan siklus II dua kali pertemuan, upaya Talking Stick dalam proses 
pembelajaran di kelompok A Paud Terpadu Darunnajah Martapura Kabupaten Banjar baik aktivitas guru, aktivitas anak, dan hasil pengembangan hasil belajar selalu mengalami peningkatan pada setiap kali pertemuan. Hasil dari faktor yang diteliti meliputi observasi aktivitas guru, observasi aktivitas anak, dan hasil belajar anak dijelaskan sebagai berikut:

\section{Aktivitas Guru}

Berdasarkan ketercapaian data aktivitas guru, maka penelitian tindakan kelas ini dikatakan berhasil dengan menggunakan langkahlangkah model pembelajaran Talking Stick. Guru berupaya agar siswa lebih termotivasi lagi dalam mengikuti pelajaran guna meningkatkan kreativitas siswa dan hasil belajarnya. Hal ini sesuai dengan pendapat Gibbs yang menyatakan bahwa kreativitas dapat dikembangkan dengan memberi kepercayaan, komunikasi yang bebas, pengarahan diri, dan pengawasan yang tidak terlalu ketat. Dari pernyataan Gibbs ini dapat menguatkan bahwa penerapan model kooperatif dalam pembelajaran dapat meningkatkan aktivitas, kreativitas dan hasil belajar siswa (Mulyasa, 2009: 164).

Model pembelajaran Talking Stick yang digunakan dalam penelitian ini merupakan salah satu tipe dalam pembelajaran kooperatif yang dapat meningkatkan motivasi dan kreativitas juga dapat meningkatkan hasil belajar siswa. Hal ini sesuai dengan pendapat Trianto (2010: 59) yaitu para ahli telah menunjukkan bahwa pembelajaran kooperatif dapat meningkatkan kinerja siswa dalam tugas-tugas akademik, unggul membantu siswa memahami konsep yang sulit dan membantu sisiwa menumbuhkan kemampuan berfikir kritis.

Guru sebagai pengajar, guru sebagai pembimbing untuk melaksanakan merencanakan tujuan dan mengidentifikasi kompetensi yang hendak dicapai, guru harus melihat keterlibatan peserta didik dalam pembelajara, dan peserta didik melaksanakan kegiatan belajar itu tidak hanya secara jasmaniah, tetapi mereka harus terlibat secara psikologis (Yelon, 2010 : Online).

\section{Aktivitas Anak}

Hasil penelitian Tindakan Kelas (PTK) dalam pembelajaran dengan menggunakan model pembelajaran Talking Stick di kelompok A Paud Terpadu Darunnajah siswa lebih aktif dalam belajar, siswa dapat memahami materi dengan cepat juga dapat mendorong siswa untuk berani, saling bekerjasama dan tepat dalam mengulang kalimat sederhana.

Talking Stick merupakan suatu model pembelajaran kooperatif yang dapat meningkatkan motivasi dan kreativitas juga dapat meningkatkan hasil belajar siswa. pembelajaran dengan model Talking Stick ini mendorong peserta didik untuk berani mengemukakan pendapat (Suprijono, 2009: 109). Meurut Huda (2011: 66) manfaat besar Talking Stick akan memperoleh hasil belajar 
yang lebih tinggi, motivasi yang lebih besar untuk belajar, dan meningkatnya rasa penerimaan sisa terhadap teman-temannya yang berasal dari latar belakang ras juga etnik yang berbeda-beda.

Melalui kegiatan bermain anak dapat melatih kemampuan bahasanya dengan cara: mendengarkan beraneka bunyi, mengucapkan suku kata atau kata, memperluas kosa kata, berbicara sesuai dengan Tata Bahasa Indonesia, dan sebagainya (Moeslichatoen, 2004: 32-33).

Gibbs dalam Mulyasa (2009: 164) menyatakan aktivitas dan kreativitas siswa dapat dikembangkan dengan memberi kepercayaan, komunikasi yang bebas, pengarahan diri dan pemngawasan yang tidak terlalu ketat. Serta berlandaskan pendapat Lazanov, yang menyatakan bahwa tugas pertama seorang guru ialah mendorong siswanya dalam belajar (Djanali, 2007: 33).

\section{Hasil Pengembangan Bahasa}

Berdasarkan hasil pengembangan anak pada siklus I dan siklus II dapat disimpulkan bahwa mengalami peningkatan hasil pengembangan bicara dalam mengulang kalimat sederhana. Begitu pula jika dibandingkan terhadap hasil pengembangan anak sebelum diadakan tindakan perbaikan, terlihat ada peningkatan hasil pengembangan yang sangat signifikan. Peningkatan hasil pengembangan tersebut dikarenakan guru telah menggunakan model pembelajaran yang tepat sesuai dengan karakteristik siswa usia 4-5 tahun (kelompok A) dan penggunaan media visual. Penggunaan media visual ternyata telah memberikan pengalaman langsung pada anak dan mereka dapat belajar melalui penglihatannya, hal ini sesuai yang dikatanan oleh Zaman (2009) bahwa menurut penelitian anak dapat pengetahuan dalam belajar melalui visualnya sebanyak $75 \%$.

Dengan menggunakan model talking stick pada pembelajaran pengembangan bahasa hasil pengembangan pada setiap pertemuan mengalami peningkatan, itu berarti model talking stick merupakan salah satu model pembelajaran yang dapat digunakan dalam materi mengerti beberapa perintah secara bersamaan

Meningkatnya hasil pengembangan anak karena anak senang dan termotivasi dalam mengikuti kegiatan pembelajaran, karena pembelajaran tidak melupakan karakteristik belajar anak yang konkrit, hierarkis, dan integratif (Anonim,2007: Online). Hal ini didukung oleh teori belajar konstruktivis bahwa seseorang tidak akan menyerap pengetahuan dengan pasif. Untuk membangun suatu pengetahuan baru peserta didik akan menyesuaikan informasi baru atau pengetahuan yang disampaikan guru dengan pengetahuan atau pengalaman yang telah dimilikinya melalui interaksi sosial dengan peserta didik lain atau dengan gurunya (Yulaelawati, 2009). Pendapat tersebut 
sejalan dengan pendapat Suprijono (2011) arti, peserta didik juga harus memiliki yang menyatakan bahwa belajar yang baik komitmen terhadap belajar dan berusaha adalah jika peserta didik terlibat secara secara aktif untuk mencapainya dalam pribadi dalam pengalaman belajarnya, kerangka kerja tertentu (Andayani,2007: karenanya pengetahuan harus ditemukan online). peserta didik sendiri agar mereka memiliki 


\section{DAFTAR PUSTAKA}

Allen, K. Eillen. 2010. Profil Perkembangan Anak : Prakelahiran Hingga Usia 12 Tahun. (Penterjemah: valentine). Jakarta: PT Indeks

Ali Nugraha. (2009). Kurikulum dan Bahan Belajar TK. Jakarta: Universitas Terbuka.

Arbiyah. (2009). Penelitian Tindakan Kelas. Banjarmasin : UNLAM.

Aisyah, S, dkk. 2007. Perkembangan dan Konsep Dasar Pengembangan Anak Usia Dini. Jakarta: Universitas Terbuka.

Arif Sri Wiyana. (2011). Model-model Pembelajaran. Banjarbaru LPMP.

Anggani, Sudono. (2010). Sumber Belajar dan Alat Permainan (Untuk Pendidikan Anak Usia Dini). Jakarta : PT. Grasindo.

Arikunto, Suharsimi. (2006). Prosedur Penelitian Suatu Pendekatan Praktik, Revisi VI. Jakarta : PT. Rineka.

Aqib, Zainal. (2009). Penelitian TindakanKelas.Bandung : YramaWidya.

Conny, R, Semiawan, Dr. (2008). Belajar dan Pembelajaran Prasekolah dan Sekolah Dasar. Jakarta : Indeks.

Dewo, Pardmono, Soenimarti. (2000). Pendidikan Anak Prasekolah. Jakarta : Rineka Cipta.

Dheini, Nurbiana, dkk. (2005). Metode Pengembangan Bahasa. Jakarta : Universitas Terbuka.

Dheini, Nurbiana, dkk (2008). Tahap - Tahap Perkembangan Bahasa. Jakarta : Universitas Terbuka.

Dimyanti \& Mudjiono. (2009). Belajar dan Pembelajaran. Jakarta: Rineka Cipta

Direktorat Pembinaan TK dan SD. (2007). Pedoman Pembelajaran Bidang Pengembangan Bahasa di Taman Kanak - Kanak. Jakarta : Kemendiknas.

Depdiknas. (2006). Kurikulum Taman Kanak - Kanak . Jakarta: Dirjen Dikdasmen.

Depdiknas. (2010). Prinsip Perkembangan Bahasa Pada Anak. Jakarta.

Furchan, Arief. (2004). Penghantar Penelitian Dalam Pendidikan. Yogyakarta: Pustaka Pelajar

Hamalik. (2004). Media Pembelajaran. Jakarta.

Iskandar \& Mustaji. (2000). Pengelolaan Sumber Belajar. University Presss IKIP Surabaya.

Ibrahim. (2004). Pembelajaran Kooperatif. Jakarta : Universitas Terbuka

Moeslichatoen. (2004). Metode Mengajar di Taman Kanak - Kanak. Jakarta: Rineka Cipta 
Mulyati, Yeti. (2003). Pendidikan Bahasa dan Sastra Indonesia Di kelas Rendah.Jakarta : Universitas Terbuka.

Masitoh, dkk. (2005). Strategi Pembelajaran TK. Jakarta: Universitas Terbuka

Ririanti R. (2007). Psikologi Pembelajaran. Banjarmasin : FKIP Program SI UNLAM.

Rusyan, Tabrani. Kegiatan Belajar Mengajar. Bandung : Remaja Roesdakarya

Rahadi. (2003). Media Pembelajaran Bagi Anak TK. Jakarta.

Santoso.(2002). Pendidikan Anak Usia Dini. Jakarta : Citra Pendidikan

Suprijono. (2010). Model Pembelajaran Anak Usia Dini. Jakarta.

Sudono, Anggani. (2002). Sumber Belajar dan Alat Permainan. Jakarta : Grasindo.

Suratno. (2005). Pengembangan Kreativitas Anak Usia Dini. Jakarta: Ditjen Dikti, Direktorat Ketenagaan, Depdiknas.

Sanjaya, Wina. (2008). Strategi Pembelajaran Berorientasi Standar Proses Pendidikan. Jakarta : Kencana Prenada Media Group.

Sujiono, Yuliani. (2009). Konsep Dasar Pendidikan Anak Usia Dini. Jakarta : PT. INDEKS.

Suriansyah, A. \& Aslamiah, Hj. (2012). Strategi Pembelajaran Anak Usia Dini. Banjarmasin : Comdes.

Sulaiman. (2011). Metode Penelitian. Banjarmasin : UNLAM.

Setiawati, Lilis dan Uzer Usman. 2001. Upaya Optimalisasi Kegiatan Belajar Mengajar. Bandung : Remaja Roesdakarya

Siskandar. 2003. Kurikulum Berbasis Kompetensi Untuk Anak Usia Dini, Buletin PADU Jurnal Ilmiah Anak Dini Usia “Menu Pembelajaran PADU”, Vol 2 No. 01, april 2003.

Sumiarti. (2008). Perkembangan Peserta Didik. Jakarta : Universitas Terbuka.

Sadiman. (2000). Media Pembelajaran Anak Usia Dini. Jakarta.

Tim Pustaka Famili. (2006). Warna - Warni Kecerdasan Anak dan Pendampingnya. Yogyakarta : Kanisius.

Trianto. (2007). Model - Model Pembelajaran Inovatif Berorientasi Konstruktivistik Konsep, Landasan Teoritik Praktis dan Implementasinya. Jakarta : Prestasi Pustaka

Udin S.(2001). Strategi Belajar Mengajar. Jakarta : Universitas Terbuka. 